Jurnal Ilmiah Untuk Mewujudkan Masyarakat Madani

ISSN 2355-309X

\title{
ANALISIS REKONSILIASI FISKAL ATAS LAPORAN KEUANGAN KOMERSIAL TERHADAP PAJAK PENGHASILAN BADAN TERUTANG PADA PT SATU CITA PROTENZA TAHUN 2014
}

\author{
Edy \\ Institut Ilmu Sosial dan Manajemen STIAMI \\ Edykusuma37@yahoo.co.id
}

\begin{abstract}
Abstrak. Rekonsiliasi fiskal atas laporan keuangan komersial terhadap pajak penghasilan badan suatu perusahaan perlu dilakukan, hal ini penting karena survey lapang menunjukkan adanya fenomena yang serjadi terjadi adanya perbedaan laporan. Salah satu diantaranya adalah laporan keuangan fiskal PT Satu Cita Protenza yang mana terdapat biaya-biaya yang seharusnya dilakukan koreksi fiskal tetapi tidak dilakukan koreksi fiskal oleh PT Satu Cita Protenza. Hal ini menyebabkan kesalahan pada pelaporan SPT dan pajak penghasilan terutang tahun 2014 PT Satu Cita Protenza. Tujuan penelitian adalah untuk mengetahui (1) Bagaimanakah pelaksanaan Rekonsiliasi Fiskal atas Laporan Keuangan Komersial sebagai dasar untuk menentukan besarnya PPh Badan Terutang tahun 2014 pada PT Satu Cita Protenza (2) Bagaimana perhitungan Pajak Penghasilan Terutang Badan pada PT Satu Cita Protenza tahun 2014.

Informan dalam penelitian ini adalah supervisor dan staf bagian pajak PT Satu Cita Protenza. Teknik Pengumpulan Data dilakukan dengan wawancara terbuka, Observasi Langsung dan Dokumentasi Tertulis. Teknik Analisis Data yang penulis gunakan dalam penelitian ini adalah menggunakan metode deductive data analysis, unitizing dan categorizing. Uji Keabsahan Data dilakukan dengan Uji Credibility, Uji Transferbility, Uji Depandability danUji Confirmability.

Hasil penelitian menyimpulkan bahwa (1) Pelaksanaan rekonsiliasi yang dilakukan oleh PT Satu Cita Protenza belum sesuai dengan ketentuan perpajakan yang berlaku, hal tersebut dapat diketahui dari pajak penghasilan, perhitungan PPh kurang bayar (PPh ps 29) Rp.13.625.361,-

; (2) Pelaksanaan perhitungan rekonsiliasi fiskal atas laporan komersial PT Satu Cita Protenza dari hasil pembukuan laporan keuangan yang diselenggarakan PT Satu Cita Protenza berdasarkan SAK ( Standar Akuntansi Keuangan), perusahaan tidak melakukan koreksi fiskal sesuai dengan prinsip taxability deductibility, hal ini dikarenakan adanya perbedaan dalam pengakuan biaya dalam rekonsiliasi fiskal.
\end{abstract}

\section{Kata Kunci : Rekonsiliasi Fiskal, Laporan Keuangan Komersial,Pajak Penghasilan Badan Terutang}

Abstract. A fiscal reconciliation of a commercial fi nancial statement against a company's corporate income tax needs to be done, which is important because field surveys indicate the occurrence of phenomena occurring in different reports. One of them is the fiscal financial statement of PT Satu Cita Protenza which there are costs that should be fiscal correction but not fiscal correction by PT Satu Cita Protenza. This led to errors in tax return reporting and income tax payable in 2014 PT Satu Cita Protenza. The purpose of this research is to find out (1) How is the implementation of Fiscal Reconciliation of Commercial Financial Statement as the basis for determining the amount of Income Tax of 2014 in PT Satu Cita Protenza (2) How to calculate Income Tax owed by Agency at PT Satu Cita Protenza 2014.

Informants in this research are supervisor and tax staff member of PT Satu Cita Protenza. Data Collection Technique is done by open interview, Direct Observation and Written Documentation. Data Analysis Techniques that the authors use in this study is to use the method of deductive data analysis, unitizing and categorizing. Test Data Validity is done by Test Credibility, Transferbility Test, Depandability Test and Test Confirmability. 
Edy, Analisis Rekonsiliasi Fiskal Atas Laporan Keuangan Komersial Terhadap Pajak Penghasilan...

The result of the research concludes that (1) The implementation of reconciliation conducted by PT Satu Cita Protenza is not in accordance with the applicable taxation provisions, it can be known from income tax, calculation of underpayment tax (PPh ps 29) Rp.13.625.361, -; (2) The implementation of the fiscal reconciliation calculation of the commercial report of PT Satu Cita Protenza from the financial accounting result conducted by PT Satu Cita Protenza based on SAK (Financial Accounting Standard), the company does not make fiscal correction in accordance with the principle of taxability deductibility, this is due to the difference in recognition of costs in fiscal reconciliation.

Keywords: Fiscal Reconciliation, Commercial Financial Statement, Income Tax of Entity

\section{Pendahuluan}

Laporan keuangan digunakan untuk menggambarkan tentang informasi keuangan serta hasil usaha perusahaan. Laporan keuangan yang disusun perusahaan biasanya harus disesuaikan dengan peraturan perpajakan. Hal ini disebabkan karena laporan keuangan perusahaan disusun sesuai Standar Akuntansi Keuangan (SAK), dimana terdapat perbedaan antara penghasilandan biaya biaya yang diperkenankan atau tidak diperkenankan dalam peraturan perpajakan.

Penyesuaian ini membuat perusahaan melakukan rekonsiliasi (koreksi) fiskal untuk memenuhi kebutuhan pelaporan perpajakan. Rekonsiliasi fiskal dilakukan agar laporan keuangan komersial sesuai dengan ketentuan perpajakan, sehingga dapat diterima sebagai laporan keuangan perpajakan. Laporan keuangan perusahaan biasanya harus disesuaikan dengan peraturan fiskal ketika laporan keuangan tersebut digunakan sebagai dasar Surat Pemberitahuan Pajak Penghasilan (SPT PPh) yang akan disampaikan ke kantor pajak. Hal ini disebabkan, laporan keuangan komersial mengacu pada Standar Akuntansi Keuangan (SAK), sedangkan laporan keuangan fiskal mengacu pada Peraturan Perpajakan. PT Satu Cita Protenza adalah badan usaha yang menyelenggarakan pembukuan sesuai dengan Standar Akuntansi Keuangan dan merupakan wajib pajak yang harus menghitung, melaporkan dan menyetorkan sendiri pajak terutang atas penghasilan yang diperolehnya berdasarkan self assessment system yang dianut oleh sistem perpajakan di Indonesia. Agar pajak yang dihitung, dilaporkan, dan disetor sesuai dengan peraturan perpajakan maka PT Satu Cita Protenza harus melakukan koreksi fiskal atas laporan keuangan komersialnya, dari penyesuaian (koreksi fiskal) yang dilakukan akan menyebabkan laba kena pajak bertambah (koreksi positif) atau laba kena pajak berkurang (koreksi negatif) yang berpengaruh terhadap besarnya pajak yang akan disetorkan oleh PT Satu Cita Protenza ke kas negara. Fenomena yang terjadi pada laporan keuangan fiskal PT Satu Cita Protenza terdapat biaya-biaya yang seharusnya dilakukan koreksi fiskal tetapi tidak dilakukan koreksi fiskal oleh PT Satu Cita Protenza. Hal ini menyebabkan kesalahan pada pelaporan SPT dan pajak penghasilan terutang tahun 2014 PT Satu Cita Protenza.

Atas dasar itulah penulis tertarik untuk mengetahui (1) Bagaimanakah pelaksanaan Rekonsiliasi Fiskal atas Laporan Keuangan Komersial sebagai dasar untuk menentukan besarnya PPh Badan Terutang tahun 2014 pada PT Satu Cita Protenza? (2) Bagaimana perhitungan Pajak Penghasilan Terutang Badan pada PT Satu Cita Protenza tahun 2014 ?

\section{Kajian Literatur Pengertian Administrasi Pajak}

Menurut Djoned Gunadi M (2011;20), administrasi pajak adalah merupakan instrument dari ketentuan formal perpajakan yang ada. Hal yang demikian ini administrasi pajak memiliki posisi yang sangat penting, tidak hanya pada pelayanan, pengawasan, dan pembinaan namun juga menyangkut hak-hak wajib yang yakin benar bahwa pelaksanaan kewajiban perpajakannya dilindungi dengan administrasi yang baik." 
Jurnal Ilmiah Untuk Mewujudkan Masyarakat Madani

ISSN 2355-309X

\section{Pengertian Pajak}

Dikutip oleh Waluyo (2010;3) pengertian pajak menurut Soeparman Soemahamidjaja yaitu:

"Pajak adalah iuran wajib berupa uang atau barang yang dipungut oleh penguasa berdasarkan norma-norma hukum, guna menutup biaya produksi barang-barang dan jasa-jasa kolektif dalam mencapai kesejahteraan umum"

\section{Fungsi Pajak}

Terdapat 2 fungsi pajak menurut Mardiasmo (2011:1), yaitu :

\section{a. Fungsi budgetair}

Pajak sebagai sumber dana bagi pemerintah untuk membiayai pengeluaranpengeluarannya.

\section{b. Fungsi mengatur (regulerend)}

Pajak sebagai alat untuk mengatur atau melaksanakan kebijaksanaan pemerintah dalam bidang sosial dan ekonomi.

\section{Sistem Pemungutan Pajak}

Official Assessment System

Pengertian Official Assessment system adalah suatu sistem pemungutan pajak yang memberi wewenang kepada pemerintah (fiskus) untuk menentukan besarnya pajak terutang oleh wajib pajak. Fiskus adalah perbendaharaan pajak. Ciri-cirinya :

1) wewenang untuk menentukan berapa besar pajak terutang yang ada pada fiskus.

2) wajib pajak bersifat pasif.

3) utang pajak akan timbul pada saat dikeluarkannya surat ketetapan pajak oleh fiskus.

\section{Self Assessment System}

Pengertian Self Assessment System adalah sistem pemungutan pajak yang memberi wewenang kepada wajib pajak untuk menentukan sendiri besarnya pajak yang terutang.

ciri-cirinya :

1) wewenang untuk menentukan besarnya pajak terutang ada pada wajib pajak sendiri
2) dalam hal ini wajib pajak aktif, mulai dari menghitung, menyetor dan melaporkan sendiri pajak yang terutang.

3) fiskus tidak ikut campur, akan tetapi hanya mengawasi.

\section{With Holding System}

Pengertian With Holding System adalah sistem pemungutan pajak yang memberi wewenang kepada pihak ketiga (bukan fiskus dan bukan wajib pajak yang bersangkutan) untuk menentukan besarnya pajak yang terutang oleh wajib pajak.

\section{Pajak Penghasilan}

Dikutip oleh Rudy Suhartono (2011:5) Pengertian Pajak Penghasilan, sesuai dengan pasal 1 Undang-Undang Pajak Penghasilan adalah pajak yang dikenakan terhadap subjek pajak atas penghasilan yang diterima dalam tahun pajak.

Menurut Mardiasmo (2011:135), mendefinisikan Pajak Penghasilan (PPh) sebagai berikut :

"Pajak Penghasilan adalah pajak yang dikenakan terhadap subjek pajak (orang pribadi, badan, Bentuk Usaha Tetap (BUT)) atas penghasilan yang diterima atau yang diperolehnya dalam tahun pajak. Sesuai dengan SAK no.46 pajak penghasilan adalah pajak yang dihitung berdasarkan peraturan perpajakan dan pajak ini dikenakan atas penghasilan kena pajak perusahaan.”

\section{Subjek Pajak Penghasilan}

Subjek pajak diartikan sebagai orang yang dituju oleh undang-undang untuk dikenakan pajak. Pajak penghasilan dikenakan terhadap Subjek Pajak berkenaan dengan penghasilan yang diterima atau diperolehnya dalam Tahun Pajak.

\section{Objek Pajak Penghasilan}

Objek Pajak Penghasilan dapat diartikan sebagai sasaran pengenaan pajak dan dasar untuk menghitung pajak terutang. Yang menjadi objek pajak $\mathrm{PPh}$ adalah penghasilan yaitu tambahan kemampuan ekonomis yang diterima atau diperoleh Wajib Pajak, baik yang berasal dari Indonesia 
Edy, Analisis Rekonsiliasi Fiskal Atas Laporan Keuangan Komersial Terhadap Pajak Penghasilan...

maupun dari luar Indonesia, yang dapat untuk konsumsi atau untuk menambah kekayaan Wajib Pajak yang bersangkutan, dengan nama dan dalam bentuk apapun.

\section{Laporan Keuangan}

Laporan keuangan terbagi menjadi dua yaitu:

\section{a. Laporan Keuangan Komersial}

Laporan Keuangan Komersial adalah laporan yang disusun dengan prinsip akuntansi yang berlaku umum yang sifatnya netral dan tidak memihak.

\section{b. Laporan Keuangan Fiskal}

Laporan Keuangan Fiskal adalah laporan keuangan yang disusun dengan menggunakan standar, metode atau praktek akuntansi sesuai dengan peraturan perpajakan yang berlaku.

\section{c. Rekonsiliasi Fiskal}

Akibat perbedaan pengakuan dalam menyusun laporan keuangan antara komersil dengan perpajakan maka perlu dilakukan penyesuaian atau rekonsiliasi fiskal. Rekonsiliasi fiskal adalah suatu mekanisme penyesuaian pelaporan keuangan wajib pajak badan menurut ketentuan komersial diubah menjadi menurut ketentuan perpajakan atau fiskal.

\section{d. Koreksi Fiskal}

Koreksi fiskal adalah koreksi atau penyesuaian yang harus dilakukan oleh wajib pajak sebelum menghitung Pajak Penghasilan $(\mathrm{PPh})$ bagi wajib pajak badan dan wajib pajak orang pribadi (yang menggunakan pembukuan dalam menghitung penghasilan kena pajak).

\section{e. Biaya Fiskal dan Non Fiskal}

\section{Biaya Fiskal}

Biaya fiskal artinya biaya yang bisa menjadi pengurang penghasilan bruto. Biaya ini dipergunakan untuk mendapatkan, menagih, dan memelihara penghasilan.

\section{Biaya Non Fiskal}

Dalam menjalankan bisnis tentunya banyak jenis pengeluaran yang menjadi biaya bagi perusahaan, namun secara pajak ada beberapa biaya yang tidak boleh dikurangkan dalam menentukan besarnya Penghasilan Kena Pajak bagi Wajib Pajak dalam negeri dan bentuk usaha tetap.

\section{f. Kredit Pajak}

Pengertian kredit pajak adalah memperhitungkan pajak penghasilan yang telah dibayar atau dipungut di muka dengan jumlah pajak yang terutang pada akhir tahun pajak. ebagaimana telah diketahui, bahwa wajib pajak dalam negeri dikenakan pajak pada saat penghasilan diperoleh atau diterima dan bersifat tidak final (dapat sebagai kredit pajak).

\section{g. Kompensasi Kerugian Fiskal}

Apabila penghasilan bruto setelah pengurangan fiskal diperoleh kerugian, maka kerugian tersebut dapat dikompensasikan dengan penghasilan mulai tahun pajak berikutnya berturut-turut sampai dengan 5 (lima) tahun.

\section{h. Pajak Penghasilan Terutang}

Pajak Penghasilan terutang adalah pajak yang harus dibayar pada suatu saat, dalam Masa Pajak, dalam Tahun Pajak, atau dalam Bagian Tahun Pajak sesuai dengan ketentuan Undang-Undang Perpajakan.

Pajak penghasilan dihitung berdasarkan tarif yang telah ditentukan dalam Undang-Undang

\section{i. Perhitungan PPh Pasal 31E}

Tarif PPh Menurut Yustinus dan Agus Priyatna (2014:186) berdasarkan Pasal 31E Undang-undang Pajak Penghasilan nomor 36 tahun 2008 dijelaskan bahwa Wajib Pajak badan dalam negeri dengan peredaran bruto sampai dengan Rp. 50.000.000.000 (lima puluh milyar rupiah) mendapat fasilitas berupa pengurangan tarif sebesar 50\% (lima puluh persen) dari tarif pasal 17 ayat 1 huruf $\mathrm{b}$ dan ayat $2 \mathrm{a}$ yang dikenakan atas Penghasilan Kena Pajak dari bagian peredaran bruto sampai dengan Rp.4.800.000.000,00 (empat milyar delapan ratus juta rupiah).

\section{j. Surat Pemberitahuan (SPT)}

Surat Pemberitahuan (SPT) adalah surat yang oleh Wajib Pajak digunakan untuk melaporkan perhitungan dan pembayaran 
Jurnal Ilmiah Untuk Mewujudkan Masyarakat Madani

ISSN 2355-309X

pajak, objek pajak dan/atau bukan objek pajak, dan/atau harta dan kewajiban sesuai dengan ketentuan peraturan perundangundangan perpajakan.

\section{Kerangka Pemikiran}

Dalam penyusunan laporan keuangan manajemen berpedoman pada Standar Akuntansi Keuangan (SAK) yang akan menghasilkan laporan keuangan yang meliputi neraca, laporan laba/rugi serta rekonsiliasi fiskal. Hal ini disebabkan karena ada beberapa penghasilan dan beban tertentu

\section{Bagan 2.1}

dalam laporan keuangan komersial yang tidak diakui oleh perpajakan dalam rangka menghitung besarnya PPh Terutang. Maka atas penghasilan dan beban-beban tersebut harus dikoreksi dari laporan keuangan komersial atau dilakukan rekonsiliasi fiskal. Selain hal tersebut penyusunan laporan keuangan perusahaan dilakukan karena adanya perbedaan tujuan antara kepentingan laporan keuangan koemersial.

Berdasarkan kerangka pemikiran diatas, maka dapat digambarkan sebuah model penelitian sebagai berikut:

Kerangka Pemikiran Analisis Rekonsiliasi Fiskal Atas Laporan Keuangan Komersial untuk Mengetahui PPh Badan Terutang pada PT Satu Cita Protenza tahun 2014

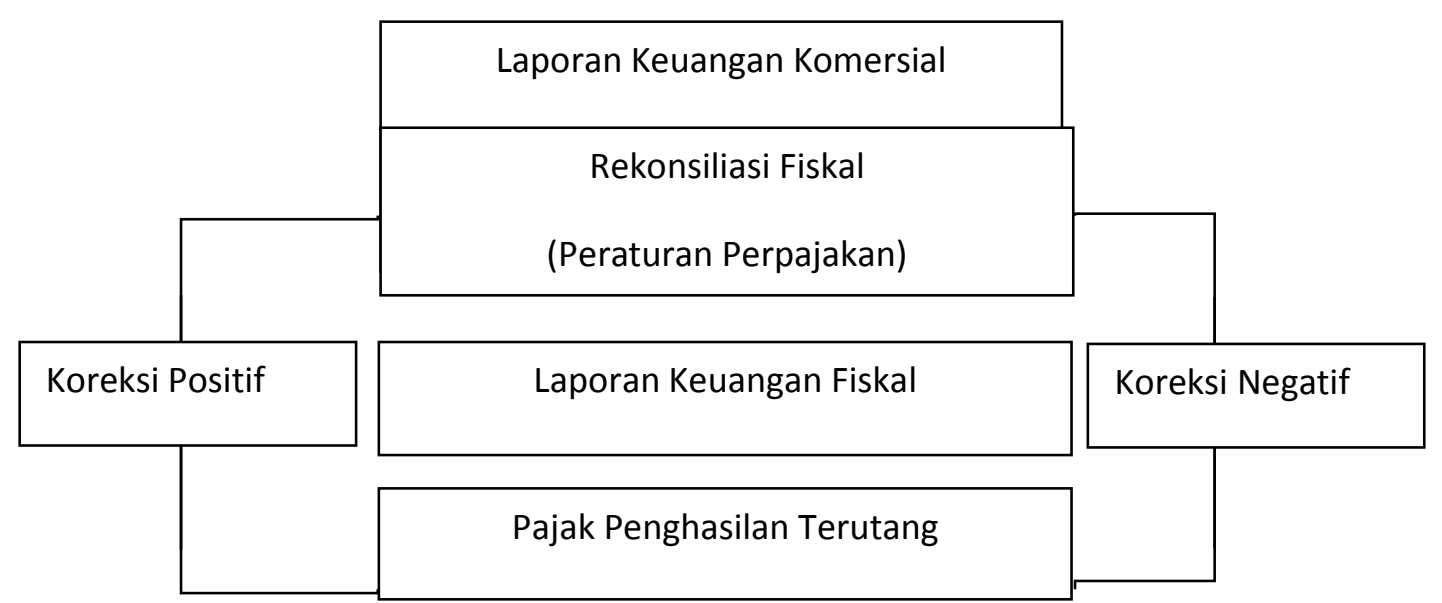

\section{Model Penelitian}

Model penelitian yang digunakan penulis dalam peneltian ini adalah metode deskriptif kualitatif dengan pendekatan survey. Beberapa indikator yang diteliti dalam penelitian ini adalah:

a. Laporan Keuangan Komersial PT Satu Cita Protenza tahun 2014

b. Laporan Keuangan Fiskal PT Satu Cita Protenza tahun 2014.

c. Perbedaan pengakuan antara standar akuntansi keuangan dan peraturan undang-undang perpajakan dalam menilai suatu lapoan keuangan perusahaan.

d. Besar pajak penghasilan badan terutang menurut perpajakan.

\section{Metode Penelitian}

\section{Pendekatan Penelitian}

Pendekatan penelitian yang penulis gunakan dalam penelitian ini adalah pendekatan deskriftif kualitatif yang terbatas pada usaha untuk mengungkap suatu masalah, keadaan, dan peristiwa yang terjadi, sehingga penelitian ini mengungkapkan fakta-fakta yang sebenarnya. Penulis menggunakan pendekatan deskriptif kualitatif karena penulis mempertimbangkan fokus penelitian dalam pencapaian tujuan yang ingin dicapai yaitu mengenai analisis rekonsiliasi fiskal atas laporan keuangan komersial terhadap pajak penghasilan badan terutang pada PT Satu Cita Protenza tahun 2014.

\section{Dimensi - Dimensi Penelitian}

1. Dimensi Tujuan Penggunaan

a. Dimensi Bersifat Murni

Dalam penelitian ini, perusahaan melakukan ketidaksesuaian dalam 
Edy, Analisis Rekonsiliasi Fiskal Atas Laporan Keuangan Komersial Terhadap Pajak Penghasilan...

pelaksanaan rekonsiliasi fiskal, oleh karena itu penulis melakukan penelitian.

b. Dimensi bersifat Terapan

Dari penelitian ini, penulis memberikan pemecahan masalah atas ketidaksesuian pelaksanaan rekonsiliasi fiskal yang dilakukan oleh perusahaan.

2. Dimensi Tujuan Penelitian

Karena itu dimensi dalam penelitian ini ditinjau dari segi tujuan penjelasan bersifat deskriptif.

3. Dimensi Waktu

Dalam penelitian ini dimensi yang penulis gunakan adalah case study atau studi kasus.

\section{Paradigma Penelitian}

Paradigma penulis dalam penelitian ini adalah paradigma naturalistik. Data-data yang diperoleh peneliti tidak diubah namun diaplikasikan sesuai dengan peraturan perpajakan yang berlaku. Peneliti berusaha memahami secara mendalam peraturan perpajakan yang berlaku dan membandingkannya dengan aplikasi yang dilakukan PT Satu Cita Protenza.

\section{Penentuan Informan}

Informan dalam penelitian ini adalah supervisor dan staf bagian pajak PT Satu Cita Protenza, karena supervisor dan staf PT Satu Cita Protenza yang melakukan pencatatan, perhitungan dan pelaporan pajak penghasilan badan terutang PT Satu Cita Protenza tahun 2014 sehingga dapat diyakini bahwa data dan informasi yang didapatkan adalah benar dan dapat dipertanggungjawabkan.

\section{Teknik Pengumpulan Data}

Teknik Pengumpulan data dilakukan dengan Wawancara terbuka, Observasi Langsung dan Dokumentasi Tertulis

\section{Teknik Analisis Data}

Analisis daa yang penulis gunakan dalam penelitian ini adalah menggunakan metode deductive data analysis, yang merupakan metode analisis umum yang dilakukan penulis yang didasarkan pada hasil penelitian lapangan. Metode ini juga digunakan untuk mengungkapkan informasi yang tersembunyi.

Dalam mengungkapkan informasi yang tersembunyi tersebut penulis juga menerapkan unitizing dan categorizing. Unitizing data mentah secara sistematis ditransformasikan dan dihimpun kepada unitunit yang cenderung memiliki deskripsi yang tepat dan inti sifat-sifat yang relevan. Sedangkan categorizing adalah proses data yang sudah diunitkan sebelumnya diorganisasikan dalam beberapa kategori sehingga tersedianya kesimpulan deskripsi atau informasi tentang kedudukan dari mana unit-unit itu berasal.

\section{A. Uji Keabsahan Data}

Untuk menentukan apakah data yang penulis peroleh dari lapangan sudah mencapai tingkat keabsahan, maka diperlukan uji keabsahan data melalui empat kriteria, yaitu:

1. Uji Credibility

Uji Credibility data atau kepercayaan terhadap data hasil penelitian kualitatif dilakukan dengan perpanjangan pengamatan.

2. Uji Transferbility

Uji transferbility dilakukan dengan memberi laproan penelitian yang memberikan uraian yang inci, jelas, sistematis dan dapat dipercaya.

3. Uji Depandability

Dalam penelitian kualitatif, uji dependability dilakukan dengan melakuakn pemeriksaan terhadap keseluruhan proses penelitian ke lapangan.

4. Uji Confirmability

Dalam penelitian kualitatif, uji confirmability mirip dengan uji depandability, sehingga pengujiannya dapat dilakukan secara bersamaan. Uji confirmability adalah menguji hasil penelitian yang dikaitkan dengan proses yang dilakukan.

\section{Lokasi dan Jadwal Penelitian}

Pada Penelitian ini, penulis mengambil lokasi penelitian di sebuah perusahaan yakni PT Satu Cita Potenza selama 4 bulan dari bulan November 2015 s/d Februari 2016. 


\section{Hasil Penelitian Dan Pembahasan}

\section{Gambaran Umum Fokus Penelitian}

Objeknya peneltian adalah laporan keuangan komersial untuk direkonsiliasi ke laporan keuangan fiskal, dimana penulis akan membandingkan dan melakukan analisis laporan keuangan fiskal yang dilakukan PT Satu Cita Protenza dengan laporan keuangan fiskal yang penulis lakukan berdasarkan Peraturan Perpajakan dalam tabel komparatif. Dalam tabel komparatif tersebut ditemukan perbedaan perhitungan koreksi fiskal antara yang dilakukan oleh PT Satu Cita Protenza dengan penulis sehingga menyebabkan perbedaan atas perhitungan $\mathrm{PPh}$ Badan Pasal 29 tahun 2014.

\section{Hasil Uji Keabsahan Data}

Berdasarkan uji keabsahan data yang diuraikan pada Bab III, maka penulis akan menjelaskan hasil uji keabsahan data sebagai berikut:

1. Mengenai kepercayaan, bahwa penulis telah mendapatkan kepercayaan dalam hal penerimaan data yang dibutuhkan dalam penelitian ini, penulis datang ke lapangan, dan penulis berhasil mendapatkan data yang dibutuhkan dalam penelitian yaitu data Laporan Keuangan Komersial, Laporan Keuangan Fiskal, Surat Setoran Pajak yang sudah divalidasi oleh Kantor penerima pembayaran /bank, tanda terima SPT Tahunan yang sudah dilaporkan ke Kantor Pelayanan Pajak setempat, Bukti Penerimaan Surat dan perhitungan rekonsiliasi keuangan fiskal perusahaan, selain itu penulis juga berhasil mewawancarai staff accounting dan tax PT Satu Cita Protenza secara tertulis maupun dengan cara tanya jawab sehingga data yang penulis terima dapat dipertanggung jawabkan. Data hasil penelitian di uji dengan metode triangulasi, yang terdiri dari source (sumber) dalam hal ini sumber data yang didapat dari lapangan yaitu PT Satu Cita Protenza, methods (metode-metode) dalam melakukan penelitian penulis menggunakan metode-metode penelitian seperti metode wawancara dengan informan, metode dokumen tertulis dan metode observasi, investigators (penelitipeneliti) penulis dalam menjalankan penelitiannya meminta saran kepada penulis yang lain untuk melihat dengan sudut pandang yang berbeda mengenai penelitian yang penulis lakukan dan theoris (teori-teori) penulis mendapatkan teori-teori yang berhubungan dengan penelitian dan menyesuaikan teori-teori yang di dapat dengan data-data yang didapatkan, dengan model triangulasi maka penelitian ini dapat dikatakan dipercaya.

2. Dalam hal ini penulis menjelaskan mengenai pelaksanaan rekonsiliasi fiskal atas laporan keuangan komersial dalam menghitung PPh Badan PT Satu Cita Protenza dan didasarkan hasil wawancara terhadap informan mengenai biaya-biaya yang akan dikoreksi maka melalui penelitian ini akan terbentuk kesamaan dan kecocokan yang saling berhubungan mengenai menentukan PPh Badan yang terutang setelah adanya koreksi fiskal. Sehingga dapat dikatakan penelitian ini memenuhi transferability.

3. Penulis melakukan penelitian mengenai analisis pelaksanaan rekonsiliasi fiskal atas laporan keuangan komersial dalam menghitung Pajak Penghasilan Badan Terutang dan dalam proses penelitian mulai dari penulisan, analisis data hingga sampai pada simpulan dan saran, seluruhnya telah diaudit oleh dosen pembimbing dengan waktu yang sudah ditentukan, sehingga dapat dikatakan bahwa proses peneltian telah dilakukan dengan benar.

4. Data yang penulis dapat telah ditegaskan kebenarannya karena bersumber dari informan yang dapat dipertanggung jawabkan kebenarannya, dan penulis melakukan konfirmasi dengan memperoleh persetujuan dari informan mengenai hasil wawancara dan data yang diterima agar dapat dipublikasikan pada penulisan skripsi ini. 
Edy, Analisis Rekonsiliasi Fiskal Atas Laporan Keuangan Komersial Terhadap Pajak Penghasilan...

\section{Strategi Analisis Data}

Pada penelitian ini, penulis melakukan pendekatan penelitian yaitu dengan cara pendekatan inductive data analysis karena data yang penulis peroleh didasarkan pada hasil penelitian lapangan, pada strategi analisis data yang penulis gunakan yaitu hermeneutic analysis yaitu analisis terhadap hasil wawancara yang telah ditransfer menjadi bahan tertulis dalam hal ini penulis melakukan wawancara kepada informan dan hasil wawancara yang didapat baik dengan menggunakan pedoman wawancara atau dengan cara lisan berupa tanya jawab secara langsung kepada informan diurakan di dalam penelitian pada analisis dan interprestasi penelitian, kemudian literary criticism (analisis kritik) memberikan teori melalui kajian literatur yang berhubungan dengan penelitian yang didapat dari beberapa referensi, strategi selanjutnya yaitu content analysis yaitu penelitian didasarkan pada isi dokumen tertulis baik berupa laporan keuangan komersial, SPT, SSP, Rekonsiliasi Fiskal dan dijelaskan secara rinci di dalam penelitian, strategi selanjutnya yaiu categorizing berdasarkan penelitian yang telah diuraikan, kemudian dijadikan suatu kesimpulan dan saran.

\section{Temuan Hasil Penelitian}

Penulis akan menyampaikan temuan hasil penelitian yang penulis dapatkan dengan cara sebagai

1. Wawancara

Wawancara langsung dengan Ibu Suwarni selaku staff bagian pajak pada PT Satu Cita Protenza, penulis mendapatkan informasi bahwa perusahan tersebut terdapat adanya perbedaan perlakuan di rekonsiliasi laporan keuangan fiskal pada koreksi fiskal positif. Hal ini disebabakan karena adanya biaya yang dapat dibebankan menjadi pengurang penghasilan (deductable expenses) dan biaya yang tidak diperkenankan sebagai pengurang dari penghasilan bruto (nondeductable expense) dari hasil wawancara dengan staf accounting didapatkan fakta bahwa PT Satu Cita Protenza dalam pembukuannya menggunakan metode accrual basic accounting dimana dalam metode ini beban diakui pada saat transaksi walaupun kas atau uang belum dibayarkan. Begitu pula dengan pendapatan dicatat pada saat transaksi walaupun kas baru akan diterima bulan depan dan dalam sistem penyusutan dan amortisasinya menggunakan straight line method (metode garis lurus) dan laporan laba/rugi untuk biaya dilakukan penggabungan selain itu dikemukakan beberapa kesalahan dalam koreksi fiskal:

a. Biaya pengisian pulsa prabayar dan berbayar fasilitas untuk Direksi dan General Manager digabung dalam 1 akun yaitu biaya telepon yang dimana seharusnya dilakukan koreksi fiscal sebesar $50 \%$ karena merupakan natura atau kenikmatan.

b. Biaya tansportasi terdapat biaya pembelian solar/premium untuk kendaraan mobil direksi seharusnya dikoreksi positif dengan perhitungan $50 \%$ dari total biaya.

c. Biaya pemeliharaan dan perbaikan terdapat biaya pemeliharaan dan perbaikan atas mobil dinas Direksi seharusnya dilakukan koreksi fiskal positif sebesar $50 \%$ atas biaya pemeliharaan dan perbaikan tersebut.

d. Dalam akun biaya overtime \& kesehatan karyawan terdapat biaya rawat inap rumah sakit karyawan yang langsung perusahaan bayar ke rumah sakit tersebut, hal tersebut merupakan natura dan harus di koreksi positif.

e. Dalam akun biaya penyusutan PT Satu Cita Protenza hanya melakukan koreksi fiskal positif sebesar $50 \%$ atas penyusutan mobil BMW X5 yang dibawa pulang oleh Direktur Utama. PT Satu Cita Protenza tidak melakukan koreksi atas biaya penyusutan Toyota G, Toyota Rush dan Mazda CX yang dibawa pulang oleh Manager PT Satu Cita Protenza. Total dari biaya penyusutan mobil dinas tersebut adalah sebesar Rp.149.905.675,- dan seharusnya dilakukan koreksi fiskal positif $50 \%$ sebesar Rp.74.952.838,sehingga dalam laporan rekonsiliasi fiskal harus di koreksi fiskal positif sebesar Rp.130.187.213,--

f. Dalam akun biaya promosi dan iklan terdapat biaya-biaya yang tidak bisa dibebankan dan harus dikoreksi positif 
seperti biaya entertainment yang tidak terdapat bukti nominatifnya, hadiah dan donasi kepada relasi kerja serta biaya promosi yang tidak terdapat bukti pendukungnya.

\section{Hasil Obervasi}

Dari hasil pengamatan langsung yang dilakukan oleh penulis pada PT Satu Cita Protenza tepatnya pada bagian accounting dan pajak, diketahui bahwa memang benar adanya perbedaan perlakuan di rekonsiliasi laporan keuangan fiskal pada koreksi fiskal positif dan koreksi fiskal negatif. PT Satu Cipta Protenza melakukan beberapa kesalahan dalam melakukan rekonsiliasi fiskal pada biaya yang seharusnya tidak boleh dikurangkan dengan penghasilan bruto.

3. Dokumen Tertulis

Selain dari wawancara dan observasi, penulis juga mengamati bukti-bukti pendukung serta dokumen terkait diantaranya berupa laporan laba-rugi, neraca dan daftar penyusutan inventaris kantor. Serta penulis mengamati laporan keuangan rekonsiliasi fiskal perusahaan yang nantinya akan diolah dan dibandingkan dengan perhitungan rekonsiliasi fiskal yang sudah diolah oleh penulis yang telah disesuaikan denggan peraturan Undang-Undang Perpajakan yang berlaku, yang mana dalam laporan keuangan komersial rekonsiliasi fiskal PT Satu Cita Protenza sudah sesuai atau tidak sesuai dengan Undang-Undang.

\section{Analisis dan Interpretasi Penelitian}

\section{Analisis Penelitian}

a. Analisis Rekonsiliasi Fiskal atas Laporan Laba Rugi Komersial PT Satu Cita Protenza tahun 2014

Sebelum menganalis lebih lanjut mengenai pengaruh rekonsiliasi fiskal terhadap besarnya pajak peghasilan terutang pada PT Satu Cita Protenza, pembahasan skripsi ini dimulai terlebih dahulu dengan menyajikan laporan keuangan yang terakhir pada tanggal 31 Desember setiap tahunnya, maka setiap perusahaan yang melakukan aktivitas dan memperoleh penghasilan dari usahanya diwajibkan untuk menyelenggarakan pembukuan. Demikian juga halnya dengan PT Satu Cita Protenza yang menyusun laporan keuangan untuk menggambarkan posisi keuangan dan kinerja perusahaan dalam tahun tersebut.

\section{1) Laporan Laba Rugi}

Setiap jangka waktu tertentu, umumnya satu tahun. Perusahaan perlu memperhitungkan hasil usaha perusahaan yang dituangkan dalam bentuk laporan labarugi. Hasil usaha perusahaan tersebut didapat dengan cara membandingkan penghasilan dengan biaya selama jangka waktu tertentu. Besarnya laba atau rugi akan diketahui dari hasil perbandingan tersebut. Laporan laba rugi adalah salah satu laporan keuangan yang menggambarkan apakah suatu perusahaan mengalami laba atau rugi dalam satu periode akuntansi. Besarnya laporan rugi-laba komersial PT Satu Cita Protenza pada tahun 2014 berdasarkan perhitungan rugi laba diperoleh sebesar Rp. 88.661.561

\section{2) Laporan Rekonsiliasi Fiskal}

Rekonsiliasi fiskal bertujuan untuk mendapatkan laba fiskal sesuai dengan peraturan perpajakan yang berlaku yang pada akhirnya dari laba tesebut dijadikan dasar untuk menentukan Pajak Penghasilan Badan. Dalam menentukan besarnya Pajak Penghasilan Badan, perusahaan perlu mengadakan penyesuaian terhadap laporan keuangan komersial agar sesuai dengan ketentuan perpajakan yang berlaku. Laporan rekonsiliasi fiskal akan menghasilkan laporan keuangan fiskal yang dapat dijadikan dasar dalam menghitung Pajak Penghasilan Badan tahun 2014 pada PT Satu Cita Protenza.

Berdasarkan hasil perhitungan laporan laporan rekonsiliasi fiskal per 31 desember 2014, Menurut PT Satu Cita Protenza, diperoleh nilai sebesar Rp 1.052.008.001.

Berdasarkan perhitungan tersebut, berikut penjelasan atas koreksi positif pada laporan keuangan PT Satu Cipta Protenza:

a. Biaya Pajak

PT Satu Cita Protenza melakukan koreksi fiskal atas biaya pajak sebesar 
Edy, Analisis Rekonsiliasi Fiskal Atas Laporan Keuangan Komersial Terhadap Pajak Penghasilan...

Rp.667.939.737,-- Biaya ini merupakan biaya pembayaran angsuran pajak penghasilan pasal 21 dan 25, serta pajak penghasilan yang bersifat final yang dikenakan atas penghasilan berupa pendapatan jasa giro yang tidak bisa dijadikan beban dalam laporan laba rugi fiskal, selain itu dalam akun biaya pajak ini juga terdapat pembayaran berupa denda pajak yang tidak boleh dikurangkan dalam laba bruto.

b. Biaya penyusutan

Metode penyusutan yang digunakan oleh PT Satu Cita Protenza adalah metode garis lurus. Adanya perbedaan biaya penyusutan antara komersial dan fiskal, dikarenakan adanya kendaraan perusahaan yaitu BMX X5 yang digunakan dan dibawa pulang oleh Direksi Utama penyusutan atas kendaraan tersebut dikenakan sebesar $50 \%$ atas biaya penyusutan yaitu sebesar Rp. 55.234.375,-

Berdasarkan perhitungan penyusutan asset per Per Desember 2014, diperoleh nilai akumulasi penyusutan sebesar $\mathrm{Rp}$ 1.362.689.975

Berdasarkan perhitungan besarnya $\mathrm{PPh}$ wajib pajak badan tahun 2014 pada PT Satu Cita Protenza per 31 Desember 2014 diperoleh bahwa besarnya penghasilan kena pajak yang sudah dikurangi kompensasi kerugian tahun sebelumnya adalah sebesar Rp. 1.052.008.001,- . Angsuran Pajak penghasilan Wajib Pajak Badan untuk tahun 2014 pada PT Satu Cita Protenza adalah sebesar Rp. 20.014.361,-

Dari laporan rekonsiliasi fiskal PT Satu Cita Protenza sebagai dasar untuk menentukan besarnya PPh Badan tahun 2014 pada PT Satu Cita Protenza terdapat biayabiaya yang merupakan non deductable expense tetapi tidak dilakukan koreksi fiskal pada laporan rekonsiliasi fiskal perusahaan. Berikut keterangan atas biaya-biaya yang harus di koreksi fiskal:

a) Biaya pengisian pulsa prabayar dan berbayar fasilitas untuk Direksi dan General Manager digabung dalam 1 akun yaitu biaya telepon yang dimana seharusnya dilakukan koreksi fiskal sebesar 50\% karena merupakan natura atau kenikmatan.

b) Biaya tansportasi terdapat biaya pembelian solar/premium untuk kendaraan mobil direksi seharusnya dikoreksi positif dengan perhitungan $50 \%$ dari total biaya.

c) Biaya pemeliharaan dan perbaikan terdapat biaya pemeliharaan dan perbaikan atas mobil dinas Direksi seharusnya dilakukan koreksi fiskal positif sebesar $50 \%$ atas biaya pemeliharaan dan perbaikan tersebut.

d) Dalam akun biaya overtime \& kesehatan karyawan terdapat biaya rawat inap rumah sakit karyawan yang langsung perusahaan bayar ke rumah sakit tersebut, hal tersebut merupakan natura dan harus dikoreksi positif.

e) Dalam akun biaya penyusutan PT Satu Cita Protenza hanya melakukan koreksi fiskal positif sebesar $50 \%$ atas penyusutan mobil BMW X5 yang dibawa pulang oleh Direktur Utama. PT Satu Cita Protenza tidak melakukan koreksi atas biaya penyusutan Toyota G, Toyota Rush dan Mazda CX yang dibawa pulang oleh Manager PT Satu Cita Protenza. Total dari biaya penyusutan mobil dinas tersebut adalah sebesar Rp.149.905.675,- dan seharusnya dilakukan koreksi fiskal positif 50\% sebesar Rp.74.952.838,- sehingga dalam laporan rekonsiliasi fiskal harus di koreksi fiskal positif sebesar Rp.130.187.213,-

f) Dalam akun biaya promosi dan iklan terdapat biaya-biaya yang tidak bisa dibebankan dan harus dikoreksi positif seperti biaya entertain yang tidak terdapat bukti nominatifnya, hadiah dan donasi kepada relasi kerja serta biaya promosi yang tidak terdapat bukti pendukungnya.

Dalam menentukan besarnya pajak penghasilan badan tahun 2014 maka perusahaan perlu mengadakan penyesuaian terhadap laporan laba rugi agar sesuai dengan ketentuan perpajakan yang berlaku. Untuk mengetahui apakah pelaksanaan rekonsiliasi fiskal yang dilakukan pada PT Satu Cita Protenza sudah sesuai dengan ketentuan perpajakan yang berlaku, maka penulis melakukan analisis terhadap laporan rekonsiliasi fiskal dari PT Satu Cita Protenza sebagai berikut:

Besarnya laporan rekonsiliasi fiskal per 31 desember 2014, menurut Perhitungan Penulis, 
diperoleh nilai keuntungan sebesar Rp. 1.191.573.570.

Hasil perhitungan besarnya PPh Wajib Pajak Badan Tahun 2014 pada PT Satu Cita Protenza per 31 Desember 2014, perhitungan PPh Badan tahun 2014 pada PT Satu Cita Protenza menurut ketentuan perpajakan untuk laba bersih fiskal setelah dilakukan koreksi fiskal adalah sebesar Rp.1.191.573.570,- dan untuk Angsuran PPh badan tahun 2014 yang diolah oleh penulis pada laporan laba rugi PT Satu Cita Protenza adalah sebesar Rp.22.669.583,-. Perhitungan wajib pajak badan menurut perusahaan dengan ketentuan perpajakan mengalami perbedaan dikarenakan terdapat beberapa biaya yang merupakan non deductable expense tetapi tidak dikoreksi oleh PT Satu Cita Protenza. Biaya tersebut diantarannya:

(a) Biaya pengisian pulsa prabayar dan berbayar fasilitas untuk Direksi dan General Manager digabung dalam 1 akun yaitu biaya telepon yang dimana seharusnya dilakukan koreksi fiskal sebesar $50 \%$ karena merupakan natura atau kenikmatan.

(b) Biaya tansportasi terdapat biaya pembelian solar/premium untuk kendaraan mobil direksi seharusnya dikoreksi positif dengan perhitungan $50 \%$ dari total biaya.

(c) Biaya pemeliharaan dan perbaikan terdapat biaya pemeliharaan dan perbaikan atas mobil dinas Direksi seharusnya dilakukan koreksi fiskal positif sebesar $50 \%$ atas biaya pemeliharaan dan perbaikan tersebut.

(d) Dalam akun biaya overtime \& kesehatan karyawan terdapat biaya rawat inap rumah sakit karyawan yang langsung perusahaan bayar ke rumah sakit tersebut, hal tersebut merupakan natura dan harus dikoreksi positif.

(e) Dalam akun biaya penyusutan PT Satu Cita Protenza hanya melakukan koreksi fiskal positif sebesar $50 \%$ atas penyusutan mobil BMW X5 yang dibawa pulang oleh Direktur Utama. PT Satu Cita Protenza tidak melakukan koreksi atas biaya penyusutan Toyota G, Toyota Rush dan
Mazda CX yang dibawa pulang oleh Manager PT Satu Cita Protenza. Total dari biaya penyusutan mobil dinas tersebut adalah sebesar Rp.149.905.675,- dan seharusnya dilakukan koreksi fiskal positif 50\% sebesar Rp.74.952.838,sehingga dalam laporan rekonsiliasi fiskal harus di koreksi fiskal positif sebesar Rp.130.187.213,-

(f) Dalam akun biaya promosi dan iklan terdapat biaya-biaya yang tidak bisa dibebankan dan harus dikoreksi positif seperti biaya entertain yang tidak terdapat bukti nominatifnya, hadiah dan donasi kepada relasi kerja serta biaya promosi yang tidak terdapat bukti pendukungnya.

Akibat hal tersebut terjadi perbedaan pada laba usaha dan PPh badan tahun 2014 yang menimbulkan perbedaan kembali pada $\mathrm{PPh}$ kurang bayar atau PPH pasal 29.

Jadi berdasarkan tabel 4.7 pada laporan rekonsiliasi fiskal pada PT Satu Cita Protenza menurut ketentuan perpajakan, penulis menyimpulkan bahwa terdapat sebuah koreksi fiskal positif dan terdapat perbedaan perlakuan dalam koreksi fiskalnya. Dari hasil analisis yang dilakukan oleh penulis didapat bahwa hasil dari koreksi fiskal positif yang sudah diolah oleh penulis berdasarkan ketentuan pepajakan yang berlaku yaitu, sebesar Rp.862.739.681,-. Untuk lebih jelasnya penulis akan menjelaskan sebagai berikut.

\section{Biaya Gaji}

Di dalam laporan keuangan komersial terdapat biaya untuk keperluan gaji karyawan sebesar Rp.4.027.256.015,-, menurut perusahaan biaya tersebut dapat dikurangkan sebagai deductable expenses (biaya yang dapat mengurangi penghasilan). Menurut penulis pembebanan gaji tersebut sudah benar merupakan deductable expense, hal tersebut sesuai dengan yang dikutip oleh Anastasia Diana dan Lilis Setiawati (2010:312) berdasarkan pasal 6 ayat 1 huruf a UndangUndang Pajak Penghasilan Nomor 36 Tahun 2008 dijelaskan mengenai biaya yang berkenaan dengan pekerjaan atau jasa termasuk upah, gaji honorarium, bonus, 
Edy, Analisis Rekonsiliasi Fiskal Atas Laporan Keuangan Komersial Terhadap Pajak Penghasilan...

gratifikasi dan tunjangan yang diberikan dalam bentuk uang dapat dijadikan sebagai biaya pengurang penghasilan bruto.

\section{Biaya Listrik}

Berdasarkan kutipan Anastasia Diana dan Lilis Setiawati (2010:312) Undang-Undang PPh Nomor 36 Tahun 2008 pasal 6 ayat 1, biaya yang berkaitan langsung dengan kegiatan operasional dan usaha perusahaan salah satunya biaya listrik, sehingga biaya listrik perusahaan sebesar Rp. 84.486.396,yang digunakan untuk kegiatan operasional perusahaan dapat dibebankan sebagai biaya dan mengurangi penghasilan bruto perusahaan.

\section{Biaya Telepon}

Dalam laporan laba rugi PT Satu Cita Protenza menyebutkan telepon sebesar Rp.174.486.395,-

Ternyata tidak semua pengeluaran biaya tersebut digunakan untuk kegiatan operasional perusahaan sehingga atas biaya telepon ini 50\% dari nilai Rp. 14.093.156,(pengisian pulsa prabayar dan berbayar) dilakukan koreksi fiskal positif senilai $\mathrm{Rp}$ 7.046.578,-

\section{Biaya Air (PAM)}

Beban air sebesar Rp. 24.756.200,- dan biaya tersebut telah dikurangkan menjadi deductable expense, keputusan tepat karena beban air termasuk ke dalam biaya yang dapat dikurangkan dari penghasilan bruto sesuai dengan pasal 6 ayat 1 Undang-Undang PPh Nomor 36 Tahun 2008 (dikutip oleh Anastasia Diana dan Lilis Setiawati (2010:312)), biaya yang berkaitan langsung dengan kegiatan usaha dapat dibebankan sebagai biaya dan mengurangi penghasilan bruto perusahaan.

\section{Biaya Alat Tulis Kantor (ATK)}

Dalam laporan laba rugi PT Satu Cita Protenza menyebutkan biaya ATK adalah sebesar Rp. 85.818.130,- dan biaya tersebut telah dikurangkan menjadi deductable expense, keputusan tepat karena biaya ATK termasuk kedalam biaya yang dapat dikurangkan dari penghasilan bruto sesuai dengan kutipan Anastasia Diana dan Lilis
Setiawati (2010:312) pasal 6 ayat 1 UndangUndang PPh Nomor. 36 Tahun 2008 biaya yang berkaitan langsung dengan kegiatan usaha dapat dibebankan sebagai biaya dan mengurangi penghasilan bruto.

\section{Biaya Perlengkapan Kantor}

Dalam laporan laba rugi PT Satu Cita Protenza menyebutkan biaya perlengkapan kantor adalah sebesar Rp. 38.223.275,- dan biaya tersebut telah dikurangkan menjadi deductable expense, keputusan tersebut tepat karena biaya perlengkapan kantor termasuk biaya yang dapat dikurangkan dari penghasilan bruto sesuai pasal 6 ayat 1 Undang-Undang PPh Nomor 36 Tahun 2008 (dikutip oleh Anastasia Diana dan Lilis Setiawati (2010:312))

\section{Biaya Transportasi}

Dalam laporan laba rugi PT Satu Cita Protenza terdapat biaya transportasi sebesar Rp.167.330.029,-

Dalam biaya tersebut terdapat pengeluaranpengeluaran atas pembelian solar dan premium untuk kendaraan dinas Direksi dan Manager sebesar Rp.20.561.111,-, biaya tersebut harus dilakukan koreksi positif karena berdasarkan Keputusan Direktorat Jenderal Pajak Nomor KEP-220/PJ/2002 tanggal 18 April 2002, bahwa biaya pemeliharaan, perbaikan rutin, pemakaian bahan bakar dari sedan hanya dapat dibebankan 50\% (lima puluh persen) dari biaya pembelian solar dan premium untuk kendaraan dinas Direksi dan Manager sebesar Rp.20.561.111,- hanya dapat diakui sebesar Rp.10.280.556,-

\section{Biaya Perjalanan Dinas}

Dalam laporan laba rugi PT Satu Cita Protenza menyebutkan biaya perjalanan dinas sebesar Rp. 14.870.000,- dan biaya tersebut dapat dijadikan sebagai deductable expense (biaya yang dapat dikurangkan dalam laporan rekonsiliasi fiskal) karena biaya perjalanan dinas tersebut digunakan untuk kegiatan dinas perusahaan di sekitar daerah Indonesia dan di dukung dengan bukti-bukti yang sah dan dapat dipertanggungjawabkan.

\section{Biaya Ekpedisi}


Biaya ekpedisi pada PT Satu Cita Protenza yaitu sebesar Rp.108.777.390,- dan biaya ekpedisi tidak perlu dikoreksi oleh perusahaan karena biaya ini dikeluarakan untuk membiayai kegiatan operasional perusahaan. Biaya ekpedisi merupakan biaya-biaya yang berkaitan langsung dengan kegiatan operasional perusahaan yang didukung bukti yang sah/dapat dipertanggungjawabkan.

\section{Biaya Perbaikan dan Pemeliharaan}

Dalam laporan laba rugi PT Satu Cita Protenza menyebutkan biaya perbaikan dan pemeliharaan adalah sebesar Rp. 47.442.607,. dalam biaya perbaikan dan pemeliharaan terdapat biaya atas perbaikan dan pemeliharaan kendaraan dinas Direksi dan Manager yaitu sebesar Rp. 13.152.976,- biaya tersebut harus dikoreksi positif sebesar $50 \%$ yaitu sebesar Rp. 6.576.488.

\section{Biaya Overtime dan Kesehatan Karyawan}

Dalam laporan laba/rugi PT Satu Cita Protenza terdapat biaya overtime dan kesehatan karyawan sebesar Rp.71.499.608,dalam biaya tersebut terdapat pembayaran cuma-cuma atas biaya perawatan karyawan yang dibayarkan langsung perusahaan ke rumah sakit sebesar Rp.12.450.000, biaya tersebut harus dikoreksi positif karena merupakan natura/kenikmatan oleh karyawan sesuai dengan kutipan Diana Sari (2014:212) Undang-Undang No 36 tahun 2008 pasal 9 ayat (1) e.

\section{Biaya Penyusutan}

Biaya penyusutan dalam laporan laba rugi PT Satu Cita Protenza adalah sebesar Rp.55.234.375,-, biaya tersebut adalah biaya penyusutan atas kendaraan dinas BMW X5 yang dibawa pulang oleh Direktur Utama. Dalam hal ini terdapat biaya penyusutan kendaraan dinas seperti Toyota Avanza, Mazda CX-5, Toyota Rush dan Toyota G yang dibawa pulang oleh Manager PT Satu Cita Protenza dan tidak dilakukan koreksi positif.
Berdasarkan perhitungan seharusnya dilakukan koreksi positif atas penyusutan kendaraan dinas yang dibawa pulang oleh Direktur dan Manager PT Satu Cita Protenza sebesar Rp.130.187.213 tetapi perusahaan hanya melakukan koreksi positif atas biaya penyusutan sebesar Rp.55.234.375,-.

\section{Biaya Pajak}

PT Satu Cita Protenza melakukan koreksi fiskal atas biaya pajak sebesar Rp.667.939.737,- Biaya ini merupakan biaya pembayaran angsuran pajak penghasilan pasal 21 dan 25, serta pajak penghasilan yang bersifat final yang dikenakan atas penghasilan berupa pendapatan jasa giro yang tidak bisa dijadikan beban dalam laporan laba rugi fiskal, selain itu dalam akun biaya pajak ini juga terdapat pembayaran berupa denda pajak yang tidak boleh dikurangkan dalam laba bruto. Denda pajak yang dimaksud adalah sanksi administasi karena Wajib Pajak tidak tertib administrasi dalam menyampaikan SPT Masa maupun SPT Tahunan.

\section{Biaya Perijinan dan Legilisasi}

Dalam laporan laba rugi PT Satu Cita Protenza terdapat biaya perijinan dan legilisasi sebesar Rp. 73.652.800,- . biaya perijinan dan legilisasi adalah biaya yang dikeluarkan atas pembayaran $\mathrm{PBB}$, biaya perpanjangan STNK, biaya perpanjangan kendaraan bermotor, biaya perpanjangan KEUR dan biaya sertifikasi dokumen. Biaya perijinan dan legilisasi merupakan deductable expense karena biaya perijinan dan legilisasi termasuk biaya yang dapat dikurangkan dari penghasilan bruto.

\section{Biaya Promosi dan Iklan}

Dalam laporan laba rugi PT Satu Cita Protenza tedapat biaya promosi dan iklan sebesar Rp 85.988.251,-. Dalam biaya promosi dan iklan tersebut terdapat pengeluaran seperti biaya entertaiment yang tidak terdapat daftar nominatif dan tidak dapat dipertanggungjawabkan, donasi serta hadiah untuk relasi sebesar Rp.28.259.110,perusahaan harus melakukan koreksi positif 
Edy, Analisis Rekonsiliasi Fiskal Atas Laporan Keuangan Komersial Terhadap Pajak Penghasilan...

atas biaya tersebut karena biaya tersebut dianggap fiktif.

\section{Biaya Asuransi}

Dalam laporan laba/rugi PT Satu Cita Protenza menyebutkan biaya asuransi sebesar Rp. 14.134.838,-. Berdasarkan kutipan Anastasia Diana dan Lilis Setiawati (2010:312) dalam bukunya yang berjudul Perpajakan menerangkan dalam UndangUndang PPh Nomor 36 Tahun 2008 Pasal 6 ayat (1) huruf a, bahwa biaya asuransi yang digunakan untuk kegiatan operasional perusahaan tidak perlu dikoreksi fiskal dan dapat dijadikan sebagai pengurang penghasilan bruto.

\section{Biaya Uji Kain}

Beban Uji Kain sebesar Rp. 9.993.500,- dan biaya tersebut telah dikurangkan menjadi deductable expense, keputusan tepat karena beban uji kain termasuk ke dalam biaya yang dapat dikurangkan dari penghasilan bruto.

\section{Biaya Pelatihan dan Seminar}

Dalam laporan laba rugi PT Satu Cita Protenza menyebutkan biaya Pelatihan dan Seminar adalah sebesar Rp. 31.112.600,- dan biaya tersebut telah dikurangkan menjadi deductable expense, keputusan tepat karena biaya biaya pelatihan dan seminar dilakukan di Indonesia dan termasuk ke dalam biaya yang dapat dikurangkan dari penghasilan bruto. Hal ini sesuai dengan yang telah dikutip oleh Anastasia Diana dan Lilis Setiawati (2010:313) dalam pasal 6 ayat $\mathrm{f}$ Undang-Undang PPh Nomor. 36 Tahun 2008 biaya yang berkaitan langsung dengan kegiatan usaha dapat dibebankan sebagai biaya dan mengurangi penghasilan bruto.
19. Biaya Admininistrasi Bank

Dalam laporan laba rugi PT Satu Cita Protenza menyebutkan biaya provisi dan administrasi bank sebesar Rp. 41.250.280,tidak perlu dikoreksi fiskal karena untuk biaya administrasi bank memanfaatkan jasa bank guna keperluan operasional perusahaan hal ini sesuai dengan yang telah dikutip oleh Anastasia Diana dan Lilis Setiawati (2010:312) dalam UU No. 36 tahun 2008 pasal 6 ayat 1 huruf a menerangkan biaya administrasi yang berkaitan secara langsung atau tidak langsung dengan kegiatan usaha dapat dijadikan sebagai pengurang penghasilan bruto.

Dalam koreksi fiskal pada tabel diatas penulis membetulkan dan mengkoreksi atas biayabiaya yang merupakan non deductable expense yang mempengaruhi besarnya pajak penghasilan badan tahun 2014. Sehingga dalam ketentuan perpajakan seluruh laporan keuangan rekonsiliasi fiskal perusahaan hanya terdapat kesalahan atas biaya telepon, biaya tranportasi, biaya perbaikan dan pemeliharaan, biaya overtime dan biaya kesehatan karyawan, biaya penyusutan serta biaya promosi dan iklan dan sudah di analisa kembali sehingga laporan keuangan rekonsiliasi fiskal perusahaan yang diolah penulis sudah sesuai dengan ketentuan perpajakan yang berlaku. Untuk lebih memperjelas perbedaan atas jumlah pajak penghasilan badan tahun 2014 pada PT Satu Cita Protenza, penulis menyusun laporan laba rugi komparatif menurut perusahaan dan ketentuan perpajakan sebagai berikut:

\section{Besarnya Laporan Laba Rugi Fiskal Komparatif Menurut PT Satu Cita Protenza dan Penulis}

Per 31 Desember 2014

\begin{tabular}{|l|r|r|r|}
\hline \multirow{2}{*}{ Uraian } & \multicolumn{3}{|c|}{ Koreksi } \\
\cline { 2 - 4 } & PT Satu Cita Protenza & Penulis & Selisih \\
\hline Penjualan & 27.648 .438 .839 & 27.648 .438 .839 & 0 \\
\hline & & & \\
\hline HPP & & & 0 \\
\hline Persediaan Awal & 5.891 .102 .756 & 5.891 .102 .756 & 0 \\
\hline Pembelian & $\underline{20.650 .619 .447}$ & $\underline{20.650 .619 .447}$ & \\
\hline
\end{tabular}


Jurnal Ilmiah Untuk Mewujudkan Masyarakat Madani ISSN 2355-309X

\begin{tabular}{|c|c|c|c|}
\hline $\begin{array}{l}\text { Barang Tersedia Untuk } \\
\text { Dijual }\end{array}$ & 26.541 .722 .203 & 26.541 .722 .203 & 0 \\
\hline Persediaan Akhir & 6.244 .582 .683 & 6.244 .582 .683 & 0 \\
\hline HPP & 20.297 .139 .520 & 20.297 .139 .520 & 0 \\
\hline Laba Kotor & 7.351.299.319 & 7.351.299.319 & $\mathbf{0}$ \\
\hline \multicolumn{4}{|l|}{ Biaya Operasi } \\
\hline Biaya Gaji & 4.027 .256 .015 & 4.027 .256 .015 & 0 \\
\hline Biaya Listrik & 84.486 .396 & 84.486 .396 & 0 \\
\hline Biaya Air & 65.245 .799 & 65.245 .799 & 0 \\
\hline Biaya Telepon & 24.756 .200 & 17.709 .622 & 7.046 .578 \\
\hline Biaya ATK & 85.818 .130 & 85.818 .130 & 0 \\
\hline Biaya Perlengkapan & 38.223 .275 & 38.223 .275 & 0 \\
\hline Biaya Transportasi & 167.330 .029 & 157.049 .474 & 10.280 .555 \\
\hline Biaya Perjalanan Dinas & 14.870 .000 & 14.870 .000 & 0 \\
\hline \multirow[t]{2}{*}{ Uraian } & \multicolumn{3}{|c|}{ Koreksi } \\
\hline & PT Satu Cita Protenza & Penulis & Selisih \\
\hline Biaya Ekspedisi & 108.777 .390 & 108.777 .390 & 0 \\
\hline $\begin{array}{l}\text { Biaya Perbaikan \& } \\
\text { Pemeliharaan }\end{array}$ & 47.442 .607 & 40.866 .119 & 6.576 .488 \\
\hline $\begin{array}{l}\text { B. Overtime \& Kesehatan } \\
\text { krywn }\end{array}$ & 71.499 .608 & 59.049 .608 & 12.450 .000 \\
\hline Biaya Penyusutan & 1.307 .455 .600 & 1.232 .502 .763 & 74.952 .837 \\
\hline Biaya Pajak & 0 & 0 & 0 \\
\hline $\begin{array}{l}\text { Biaya Perijinan dan } \\
\text { Legilisasi }\end{array}$ & 73.652 .800 & 73.652 .800 & 0 \\
\hline Biaya Promosi dan Iklan & 85.988 .251 & 57.729 .141 & 28.259 .110 \\
\hline Biaya Asuransi & 14.134 .838 & 14.134 .838 & 0 \\
\hline Biaya Uji Kain & 9.993 .500 & 9.993 .500 & 0 \\
\hline $\begin{array}{l}\text { Biaya Pelatihan dan } \\
\text { Seminar }\end{array}$ & 31.112 .600 & 31.112 .600 & 0 \\
\hline Total Biaya & 6.258.041.038 & 6.118.475.469 & 139.565.569 \\
\hline \multicolumn{4}{|l|}{$\begin{array}{l}\text { Pendapatan \& B. Lain- } \\
\text { Lain }\end{array}$} \\
\hline $\begin{array}{l}\text { Pendapatan Jasa Giro } \\
\text { Bank }\end{array}$ & 0 & & 0 \\
\hline Biaya Administasi Bank & 41.250 .280 & 41.250 .280 & 0 \\
\hline Total Biaya Lain Lain & 41.250 .280 & 41.250 .280 & 0 \\
\hline Total Biaya & 6.299.291.318 & 6.159 .725 .749 & 13.565 .569 \\
\hline $\begin{array}{l}\text { Laba Rugi Bersih Sblm } \\
\text { Pajak }\end{array}$ & 1.052.008.001 & 1.191.573.570 & 139.565 .569 \\
\hline PPH Terutang & 240.172.328 & 272.035.001 & 31.862 .673 \\
\hline $\begin{array}{l}\text { PPH Ps } 29 \text { (Kurang } \\
\text { Bayar) }\end{array}$ & 13.625 .361 & 45.488.034 & 31.862.673 \\
\hline Angsuran PPh Tahun & 20.014.361 & 22.669 .583 & 2.655 .222 \\
\hline
\end{tabular}


Berdasarkan tabel diatas terdapat beberapa selisih antara besarnya PPh Badan 2014 yang diakui oleh PT Satu Cita Protenza dan ketentuan perpajakan karena adanya perbedaan perlakuan biaya-biaya dalam rekonsiliasi fiskal, perbedaan tersebut di akibatkan karena adanya beberapa koreksi positif diantaranya:

(a) Dalam biaya telepon terdapat biaya untuk pembelian pulsa untuk karyawan dan direksi seharusnya biaya tersebut dilakukan koreksi positif sebesar 50\% dari total biaya pembelian pulsa sesuai dengan ketentuan perpajakan.

(b) Dalam biaya transportasi terdapat biaya pembelian solar dan premium untuk kendaraan dinas yang dibawa pulang oleh direksi dan manager, atas biaya tersebut seharusnya dilakukan koreksi fiskal sebesar $50 \%$.

(c) Terdapat biaya perbaikan dan pemeliharaan untuk kendaraan dinas Direksi dan Manager, atas biaya tersebut seharusnya dilakuakan koreksi fiskal sebesar $50 \%$.

(d) Dalam biaya overtime dan kesehatan karyawan terdapat biaya pengobatan secara cuma-cuma atas pembayaran biaya perawatan dan penginapan karyawan yang dibayarkan langsung ke rumah sakit. Biaya tersebut adalah non deductable expense dan tidak dapat dikurangkan pada penghasilan bruto karena merupakan kenikmatan yang diberikan kepada karyawan.

(e) Dalam akun biaya penyusutan PT Satu Cita Protenza hanya melakukan koreksi fiskal positif sebesar $50 \%$ atas penyusutan mobil BMW X5 yang dibawa pulang oleh Direktur Utama. PT Satu Cita Protenza tidak melakukan koreksi atas biaya penyusutan Toyota G, Toyota Rush dan Mazda CX yang dibawa pulang oleh Manager PT Satu Cita Protenza. Total dari biaya penyusutan mobil dinas tersebut adalah sebesar Rp.149.905.675,- dan seharusnya dilakukan koreksi fiskal positif 50\% sebesar Rp.74.952.838,- sehingga dalam laporan rekonsiliasi fiskal harus di koreksi fiskal positif sebesar Rp.130.187.213,-

(f) Dalam biaya promosi dan iklan terdapat biaya entertain yang tidak disertai dengan daftar nomintifnya/bukti pendukung serta biaya atas hadiah dan donasi yang diberikan kepada relasi kerja. Biaya tersebut harus dikoreksi fiskal karena

(g) merupakan non deductable expense.

Akibat dari koreksi tersebut laba usaha sebelum pajak naik dari sebesar Rp. 1.052.008.001,- (menurut PT Satu Cita Protenza) menjadi sebesar Rp.1.191.573.570,(menurut ketentuan perpajakan). Dan Angsuran PPh Badan Tahun 2014 menurut PT Satu Cita Protenza adalah sebesar Rp. 20.014.361 menjadi sebesar Rp. 22.669.583,(menurut ketentuan perpajakan) sehingga selisih perbandingannya adalah sebesar Rp.2.656.222,- atau sekitar 13\%.

\section{b. Perhitungan Pajak Penghasilan Terutang Badan Pada PT Satu Cita Protenza tahun 2014}

Berdasarkan hasil analisis yang dilakukan penulis terhadap rekonsiliasi fiskal PT Satu Cita Protenza, maka besarnya Pajak Penghasilan Wajib Pajak Badan dapat diperhitungkan dari laba bersih sebelum pajak sebesar Rp1.191.573.567,-. Maka besarnya Pajak Penghasilan PT Satu Cita Protenza untuk tahun pajak 2014 yang terutang sebagai berikut:

Berdasarkan yang telah dikutip oleh Yustinus Prastowo (2014:186) dalam pasal 31E ayat (1) UU No. 36 Tahun 2008, dimana Wajib Pajak badan dalam negeri dengan peredaran bruto sampai dengan 50.000.000.000,- (lima puluh miliar rupiah) mendapat fasilitas berupa pengurangan tarif sebesar 50\% (lima puluh persen) dari tarif sebagaimana dimaksud dalam pasal 17 ayat (1) huruf b dan ayat (2a) yang dikenakan atas Penghasilan Kena Pajak dari bagian peredaran bruto sampai dengan Rp.4.800.000.000,(Empat Miliar Delapan Ratus Juta Rupiah), maka perhitungan pajak terutangnya sebagai berikut: 
Jurnal Ilmiah Untuk Mewujudkan Masyarakat Madani ISSN 2355-309X

Karena perusahaan ini memiliki peredaran bruto lebih dari Rp.4.800.000.000,tetapi tidak lebih dari Rp.50.000.000.000,maka ada sebagian dari Penghasilan Kena Pajaknya yang dihitung dengan tarif $12,5 \%$ dan ada sebagian yang lain yang tetap dihitung dengan tarif $25 \%$.

Berdasarkan perhitungan diatas, PT Satu Cita Protenza mengalami kurang bayar sebesar Rp45.488.034,- pembayaran $\mathrm{PPh}$ pasal 29 (kurang bayar) tersebut harus disetor/dibayar paling lambat sebelum Surat Pemberitahuan (SPT) Tahunan PPh Badan disampaikan/dilaporkan.

Selain itu, PT Satu Cita Protenza juga berkewajiban untuk mengangsur PPh Pasal 25 sebesar Rp. 22.669.583,- per bulan. Penyetoran PPh Pasal 25 dilakukan paling lambat tanggal 15 (lima belas) bulan berikutnya setelah masa pajak (bulan) berakhir sedangkan untuk pelaporannya paling lambat tanggal 20 (dua puluh) bulan berikutnya setelah masa pajak (bulan) terakhir.

Besar angsuran pajak dalam tahun pajak berjalan harus disetor sendiri oleh wajib pajak untuk setiap masa pajak adalah sebesar yang terutang pada tahun pajak sebelum dikurangi dengan pemotongan dan pemungutan serta pajak yang dibayar sendiri atau tertang di luar negeri. Dan besarnya PPh pasal 25 dapat langsung dibagi dengan banyaknya masa pajak. Apabila perusahaan tersebut terdapat sisa kompensasi kerugian atau penghasilan tidak teratur maka perusahaan harus menghitung kembali besarnya angsuran PPh Pasal 25 untuk tahun berikutnya.

Sedangkan pada PT Satu Cita Protenza tidak terdapat adanya kompensasi kerugian maupun pendapatan tidak teratur sehingga besarnya Pajak Penghasilan Pasal 25 dapat langsung membagi 12 (banyaknya bulan dalam tahun pajak) dengan jumlah pajak terutang. Maka besarnya Pajak Penghasilan 25 sebesar Rp. 22.669.583,-/ bulan.

\section{Interpretasi Penelitian}

Dalam analisis penelitian tentang pelaksanaan rekonsiliasi fiskal dalam menentukan besarnya pajak penghasilan badan tahun 2014 pada PT Satu Cita Protenza, dapat diketahui hasil interprestasi penelitian yaitu perbedaan atas jumlah pajak penghasilan badan tahun 2014 menurut PT Satu Cita Protenza dengan ketentuan perpajakan, dalam perhitungan atas jumlah pajak penghasilan badan tahun 2014 pada PT Satu Cita Protenza terdapat perbedaan dengan perhitungan ketentuan perpajakan yang sudah diolah penulis, dikarenakan dalam koreksi fiskal perusahaan mengalami ketidaksesuaian dengan ketentuan perpajakan sehingga diperoleh laba usaha yang berbeda, yaitu laba usaha sebelum pajak menurut PT Satu Cita Protenza sebesar Rp.1.052.008.000,- dan laba usaha menurut ketentuan perpajakan sebesar Rp.1.191.573.569,- perbedaan ini terjadi dikarenakan dalam penghitungan laporan koreksi fiskal perusahaan pada fiskal positif yaitu pada biaya berikut ini:

a. Dalam biaya telepon terdapat biaya untuk pembelian pulsa untuk karyawan dan direksi seharusnya biaya tersebut dilakukan koreksi positif sebesar 50\% dari total biaya pembelian pulsa sesuai dengan ketentuan perpajakan.

b. Dalam biaya transportasi terdapat biaya pembelian solar dan premium untuk kendaraan dinas yang dibawa pulang oleh direksi dan manager, atas biaya tersebut seharusnya dilakukan koreksi fiskal sebesar $50 \%$.

c. Terdapat biaya perbaikan dan pemeliharaan untuk kendaraan dinas Direksi dan Manager, atas biaya tersebut seharusnya dilakuakan koreksi fiskal sebesar $50 \%$.

d. Dalam biaya overtime dan kesehatan karyawan terdapat biaya pengobatan secara cuma-cuma atas pembayaran biaya perawatan dan penginapan karyawan yang dibayarkan langsung ke rumah sakit. Biaya tersebut adalah non deductable expense dan tidak dapat dikurangkan pada penghasilan bruto karena merupakan kenikmatan yang diberikan kepada karyawan hal tersebut sesuai dengan UU no 36 tahun 2008 pasal 9 ayat e.

e. Dalam akun biaya penyusutan PT Satu Cita Protenza hanya melakukan koreksi 
Edy, Analisis Rekonsiliasi Fiskal Atas Laporan Keuangan Komersial Terhadap Pajak Penghasilan...

fiskal positif sebesar $50 \%$ atas penyusutan mobil BMW X5 yang dibawa pulang oleh Direktur Utama. PT Satu Cita Protenza tidak melakukan koreksi atas biaya penyusutan Toyota G, Toyota Rush dan Mazda CX yang dibawa pulang oleh Manager PT Satu Cita Protenza. Total dari biaya penyusutan mobil dinas tersebut adalah sebesar Rp.149.905.675,- dan seharusnya dilakukan koreksi fiskal positif $50 \%$ sebesar Rp.74.952.838,sehingga dalam laporan rekonsiliasi fiskal harus di koreksi fiskal positif sebesar Rp.130.187.213,-

f. Dalam biaya promosi dan iklan terdapat biaya entertain yang tidak disertai dengan daftar nomintifnya/bukti pendukung serta biaya atas hadiah dan donasi yang diberikan kepada relasi kerja. Biaya tersebut harus dikoreksi fiskal karena merupakan non deductable expense.

Berdasarkan hasil perhitungan besarnya selisih Angsuran PPh Tahun 2014 adalah Rp.2.655.222,- atau senilai 13\%, dikarenakan terdapat biaya seperti biaya gaji, biaya listrik, biaya tranportasi, biaya perbaikan dan pemeliharaan, biaya overtime dan kesehatan karyawan, biaya penyusutan serta biaya promosi dan iklan yang terdapat komponen-komponen biaya yang harus dikurangkan dari penghasilan bruto karena merupakan non dedutable expense, sehingga laba usaha mengalami kenaikan dari Rp.1.052.008.000,- (menurut PT Satu Cita Protenza) menjadi sebesar Rp.1.191.573.569,(menurut ketentuan perpajakan). Untuk angsuran pph badan tahun 2014(menurut PT Satu Cita Protenza) adalah sebesar Rp.20.014.60,- menjadi sebesar Rp.22.669.583- (menurut ketentuan perpajakan) sehingga selisihnya adalah sebesar Rp.2.655.222,- atau senilai $13 \%$.

Rekonsiliasi fiskal yang dilakukan oleh perusahaan ataupun ketentuan perpajakan sangat berpengaruh dalam menentukan besarnya PPh Badan tahun 2014 serta laba setelah -pajak dan sesuai atau tidak kesesuaian menurut ketentuan perpajakan yang berlaku. Berdasarkan uraian yang telah dibuat sebelumnya, maka dapat dibuat sebuah tabel rekapitulasi. Untuk mengetahui selisih pembayaran pajak penghasilan tahun 2014 secara jelas. dihitung besarnya perhitungan laba bersih sebelum pajak yang diperoleh perusahaan tahun 2014 adalah sebesar Rp.1.052.008.000,-. Sedangkan berdasarkan perhitungan laba/rugi yang dilakukan penulis, besarnya laba bersih sebelum pajak meningkat menjadi sebesar Rp.1.191.573.569,--. Pada perhitungan rekonsiliasi perusahaan hanya melakukan koreksi fiskal terhadap biaya penyusutan kendaraan dan pajak. Kemudian seharusnya perlu adanya koreksi fiskal untuk biaya listrik, biaya transportasi, biaya perbaikan dan pemeliharaan, biaya overtime dan kesehatan karyawan, biaya penyusutan serta biaya promosi dan iklan yang di dalam biaya tersebut terdapat komponen-komponen biaya yang tidak sesuai dengan ketentuan perpajakan.

Berdasarkan tabel 4.12 di atas, besarnya pajak penghasilan terutang berdasarkan perhitungan laba/rugi yang dilakukan oleh perusahaan sebesar Rp.240.172.328,-. Sedangkan menurut penulis, besarnya pajak penghasilan yang terutang meningkat menjadi Rp.272.035.001,--. Selisih pajak penghasilan yang terutang antara keduanya sebesar Rp.31.862.674,--.

Besarnya pajak penghasilan yang dihasilkan berdasarkan perhitungan laba/rugi yang dilakukan perusahaan mengalami kurang bayar ( $\mathrm{PPh}$ Pasal 29) sebesar Rp.13.625.261,- sedangkan menurut penulis sebesar Rp.45.488.034,-. Sehingga menurut analisis penulis, perusahaan mengalami kurang bayar dan akan menerima Surat Ketetapan Pajak Kurang Bayar (SKPKB) yang disertai dengan sanksi administrasi berupa bunga $2 \%$ per bulan ditambah dengan sanksi kenaikan sebesar 50\% dari kekurangan pajak tersebut serta dapat dilakukan pemeriksaan oleh fiskus.

Berdasarkan tabel 4.12 di atas, besarnya Pajak Penghasilan Pasal 25 setelah dilakukan perhitungan laba/rugi oleh perusahaan sebesar Rp. 20.014.360,-. Sedangkan menurut penulis perhitungan PPh Pasal 25 meningkat menjadi sebesar Rp.22,699.582,-. Perbedaan ini disebabkan karena kenyataanya pajak terutang yang telah dibayar lebih kecil dari Pajak Penghasilan yang seharusnya dibayarkan. 
Apabila Wajib Pajak dengan kemauan sendiri membetulkan SPT yang mengakibatkan hutang pajak menjadi lebih besar dengan syarat Direktorat Jenderal Pajak belum melakukan pemeriksaan dikenai sanksi administrasi berupa bunga $2 \%$ per bulan atas jumlah pajak yang kurang bayar, dihitung sejak saat penyampaian SPT terakhir sampai dengan tanggal pembayaran, dan bagian dari bulan dihitung penuh satu bulan.

Berdasarkan data tersebut angsuran Pajak Penghasilan Pasal 25 harus dibayar atau disetorkan selambat-lambatnya pada tanggal 15 bulan takwin berikutnya setelah masa pajak berakhir, dan Wajib Pajak diwajibkan menyampaikan SPT Masa selambatlambatnya 20 hari setelah masa pajak berakhir.

\section{Kesimpulan}

Menurut hasil analisis dan berdasarkan pembahasan serta uraian yang telah dikemukakan pada bab-bab sebelumnya mengenai analisis pelaksanaan rekonsiliasi fiskal atas laporan keuangan komersial sebagai dasar untuk menentukan besarnya PPh Badan Terutang pada PT Satu Cita Protenza tahun 2014, maka dapat ditarik kesimpulan sebagai berikut:

1. Pelaksanaan rekonsiliasi yang dilakukan oleh PT Satu Cita Protenza belum sesuai dengan ketentuan perpajakan yang berlaku, hal tersebut dapat diketahui dari pajak penghasilan, perhitungan $\mathrm{PPh}$ kurang bayar (PPh ps 29) Rp.13.625.361,dan menurut penulis sebesar Rp.45.488.034,- sehingga selisih PPh kurang bayar (PPh ps 29) pada akhir tahun adalah sebesar Rp.31.862.674,--

2. Pelaksanaan perhitungan rekonsiliasi fiskal atas laporan komersial PT Satu Cita Protenza dari hasil pembukuan laporan keuangan yang diselenggarakan PT Satu Cita Protenza berdasarkan SAK ( Standar Akuntansi Keuangan), perusahaan tidak melakukan koreksi fiskal sesuai dengan prinsip taxability deductibility, hal ini dikarenakan adanya perbedaan dalam pengakuan biaya dalam rekonsiliasi fiskal. Penulis menemukan terdapat beban yang perusahaan telah keliru atau tidak melakukan koreksi fiskal positif.

\section{Saran}

Berdasarkan kesimpulan yang telah penulis uraikan diatas, maka penulis mencoba memberikan saran-saran sebagai berikut:

1. Perusahaan harus terus mengikuti perkembangan ketentuan perpajakan di Indonesia karena ketentuan perpajakan senantiasa mengalami perubahan dan pembahasan.

2. Perusahaan melakukan rekonsiliasi fiskal kembali terhadap akun-akun pada laporan keuangan komersial dengan mengacu kepada ketentuan perpajakan yang berlaku untuk menghindari kesalahan dalam perhitungan pajak penghasilan badan terutang.

\section{Daftar Pustaka}

Djoned Gunadi M, 2005, Administrasi Pajak, Jakarta : BPPK DEPKEU RI

Mardiasmo,2011,Perpajakan,Edisi Revisi, Andi: Yogyakarta

Prastowo, Yustinus dan Agus Priyatna, 2014. Pintar Menghitung Pajak. Swadaya Grup, Jakarta

Waluyo. 2010. Perpajakan Indonesia, Edisi 9 Buku 1. Penerbit Salemba Empat : Jakarta

Wirawan B.Ilyas dan Rudy Suhartono, 2012.Hukum Pajak Material 1: Seri Pajak Penghasilan .

Salemba Humanika 